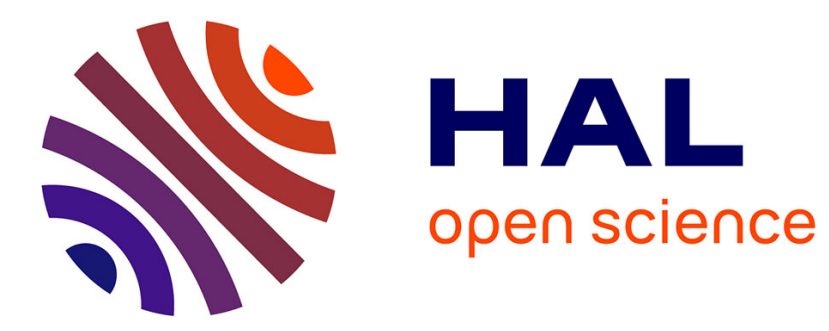

\title{
Implementing the concept of Product-Driven Control using Wireless Sensor Networks: some experiments and issues
}

David Gouyon, Michael David

\section{- To cite this version:}

David Gouyon, Michael David. Implementing the concept of Product-Driven Control using Wireless Sensor Networks: some experiments and issues. 17th IFAC World Congress, Jul 2008, Séoul, South Korea. pp.5488-5493, 10.3182/20080706-5-KR-1001.3154 . hal-00321465

\section{HAL Id: hal-00321465 \\ https://hal.science/hal-00321465}

Submitted on 15 Sep 2008

HAL is a multi-disciplinary open access archive for the deposit and dissemination of scientific research documents, whether they are published or not. The documents may come from teaching and research institutions in France or abroad, or from public or private research centers.
L'archive ouverte pluridisciplinaire HAL, est destinée au dépôt et à la diffusion de documents scientifiques de niveau recherche, publiés ou non, émanant des établissements d'enseignement et de recherche français ou étrangers, des laboratoires publics ou privés. 


\title{
Implementing the concept of Product-Driven Control using Wireless Sensor Networks: some experiments and issues
}

\author{
David Gouyon*, Michael David* \\ * Centre de Recherche en Automatique de Nancy (CRAN), UMR 7039 CNRS Nancy-Université \\ Faculté des Sciences et Techniques, BP 239, Vandoeuvre-lès-Nancy Cedex. \\ david.gouyon@cran.uhp-nancy.fr; michael.david@cran.uhp-nancy.fr
}

\begin{abstract}
In the dynamically moving context of mass-customization of products, new manufacturing control architectures, based on the consideration of highly distributed, autonomous, adaptable and efficiently cooperating units integrated by a plug-and-operate approach, seem to be efficient alternatives. Amongst them, the concept of a product-driven distributed control promotes an active role of the product in its own manufacturing. This paper focuses on the possibilities to implement this concept on a case study using wireless sensor networks.
\end{abstract}

\section{FROM INTEGRATED TO AGILE MANUFACTURING CONTROL}

Advances in the use of Information Technologies in manufacturing systems give manufacturers an opportunity to promote make-to-order business models and mass customization of products (Da Silveira et al. 2001). Facing this wide range of customized customer orders impacts the whole set of enterprise information and control systems (Nof et al. 2006), which integration capability has to be improved according to the Enterprise Integration Capability Model (Hollocks et al. 1997) (EICM Fig. 1), in a dynamically moving context.

\begin{tabular}{||c|c|}
\hline Adaptable & Intelligent system \\
\hline \hline Interoperable & Distributed system \\
\hline \hline Visible & Integrated system \\
\hline \hline Rigid & Hierarchic system \\
\hline \hline Fragmented & Fragmented system \\
\hline \hline
\end{tabular}

Fig. 1. Enterprise Integration Capability Model

Standards, as the IEC/ISO 62264 (ISO 2003) promoted by the MESA (Manufacturing Enterprise Solutions Association, http://www.mesa.org), the ISA (Instrumentation, Systems, and Automation Society, http://www.isa.org) and the ISO (International Organisation for Standardisation, http://www.iso.org), enable manufacturing enterprise-control system integration from the business level to the process level in order to meet industry-led Business-to-Manufacturing issues (Morel et al. 2003) (Fig. 2a). In this context, Manufacturing Execution Systems (MES) ensure information flow synchronic gateway between enterprise and shop floor control systems and diachronic integration between execution activities (service flows). The main issue is then to ensure consistency of information and product flows.
A possible alternative, in order to reach the 'interoperable' level of EICM, is to put into question the hierarchical/integrated vision of the enterprise-wide control for a more interoperable or intelligent one by postulating the customized product as the 'controller' of the manufacturing enterprise resources (McFarlane et al. 2003, Morel et al. 2005) (Fig. 2b). The product, seen as a good by manufacturing systems, and as information and service supplier by business systems, ensures consistency between physical and informational flows.

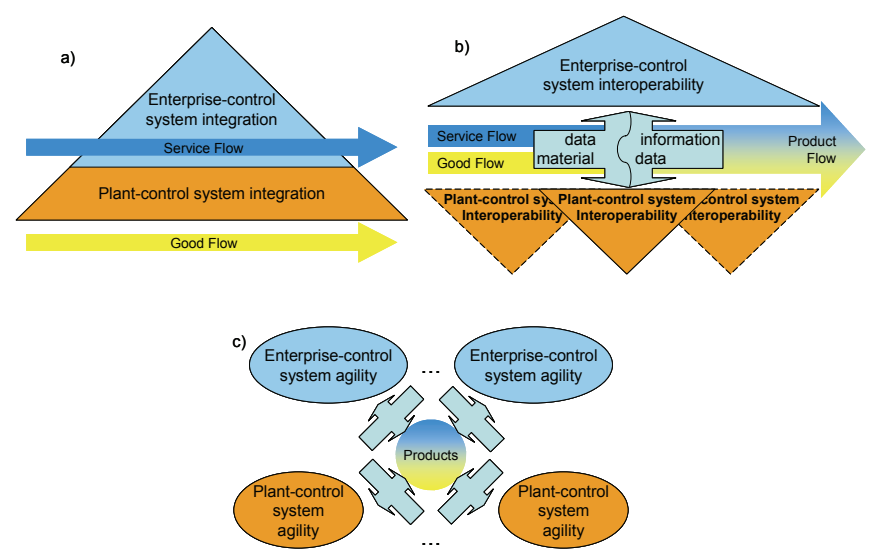

Fig. 2. From Integrated to agile manufacturing

Another alternative (Fig. 2c), as promoted by the IMS community, leads to the development of new architectures based on the consideration of highly distributed, autonomous, adaptable and efficiently cooperating units integrated by a plug-and-operate approach, as done in multi-agent (Marik \& Lazansky 2006) and Holonic Manufacturing Systems (Deen 2003). Such an approach is also currently studied by the European Project "Pabadis-Promise", which aims at 
extending the idea of distributed control to an innovative architecture which incorporates both resource and product (http://www.pabadis-promise.org). Emerging infotronic technologies embedded into product-driven control (McFarlane et al. 2003) bring more or less research results closer to actual deployment: Radio Frequency IDentification (RFID), wireless networking, modern PLC and industrial PC support of multi-agent systems...

This paper focuses on the possibilities to implement the product-driven control concept with such infotronics technologies. After a description in section 2 of the concept of product-driven control, a comparison is made in section 3 between RFID tags and Wireless Sensor Networks (WSN) motes to foresee which product intelligence levels can be implemented. Section 4 presents a case study on which experiment are being made with WSN motes.

\section{PRODUCT-DRIVEN CONTROL}

As the work presented in this paper is mainly focused on the implementation of a product-driven control, this part aims first at describing the concept.

\subsection{Intelligent versus smart product}

Considering an active role of the product leads to give it a form of technical intelligence (Karkkainen et al. 2003), which corresponds, according to (Wong et al. 2002), to:

1 Possess a unique identity,

2 Be capable of communicating effectively with its environment,

3 Be able to retain or store data about itself,

4 Deploy a language to display its features, production requirements etc.,

5 Be capable of participating in or making decisions relevant to its destiny.

In function of these points, two levels are defined in Wong et al. 2002:

- Level 1 Product Intelligence allows a product to communicate its status (form, composition, location, key features), i.e. it is information oriented. Level 1 essentially covers points 1 to 3 of the intelligent product definition above.

- Level 2 Product Intelligence allows a product to assess and influence its function (e.g. self-distributing inventory and self-manufacturing inventory) in addition to communicating its status, i.e. it is decision oriented. Level 2 therefore covers points 1 to 5 of the intelligent product definition above.

From an operational point of view, things can be very different because it seems to be difficult to implement directly into smart products all aspects of product intelligence. At this time, much embedded devices have neither enough processing power nor the ability to communicate all the required information for the manufacturing. For these reasons, some other cases can be envisaged if active entities reside in computers and are remotely linked to physical products and machines. Indeed, some multi-agent manufacturing systems are already implemented in real industrial environment (McFarlane et al. 2003), but there are some constraints, related for example to the reliability of RFID: successful read rate is not yet $100 \%$, and for this reason, the system may not be fully observable.

In such an approach, the product is considered as central to the automation rationale, and is logically provided with information, decision and communication capabilities in order to make it active in the scheduling and the execution of its manufacturing operations (point 5 of Wong et al. 2002). The system is then said "product-driven". Holonic Manufacturing Systems (HMS) constitute a repository to formalize this concept of product-driven control.

\subsection{Holonic Manufacturing Systems}

Koestler (Koestler 1967) introduced the concept of the Holon, which is an entity capable of functioning as a whole, while simultaneously acting as a part of a whole in a hierarchically ordered system. In other words, a Holonic system is a combination of an heterarchical system with centralised elements. Based on this concept, the IMS community, especially in the area of Holonic Manufacturing Systems (Valckenaers 2001, Deen 2003, Leitao \& Restivo 2006) promotes conceptual architectures, which tend towards providing manufactured product with an intelligent behaviour. These HMS (Babiceanu \& Chen 2006) are distributed systems which consider holons, which can be autonomous production units, cooperating to make products in a dynamically reconfigurable environment (McFarlane et al. 2003). In the HMS reference architecture PROSA (Van Brussel et al. 1998), types of holons are resource holons, order holons, staff holons and product holons, this last concept showing explicitly the active role of products.

A very interesting point with HMS is that Chirn and McFarlane evaluated that this approach can provide higher reconfigurability and modularity when facing series of design changes (Chirn \& McFarlane 2005).

\subsection{Product-Driven Automation}

Following conceptual guidelines of HMS, the approach used in this work focuses on the design of a product-driven distributed control system (Fig. 3) (Pétin et al. 2007), which is based on the cooperation between:

- product controllers which control the manufacturing routes according to a scheduled list of operations the product has to undergo; these controllers are specific for each product occurrence in order to take into account their customization,

- resource controllers which ensure correct execution of transport and transformation operations and provide the product controllers with accurate reports; control flexibility relies on tuning call parameters of the functional objects which coordinate and control the elementary operations, or on downloading specific control policies embedded into products. 


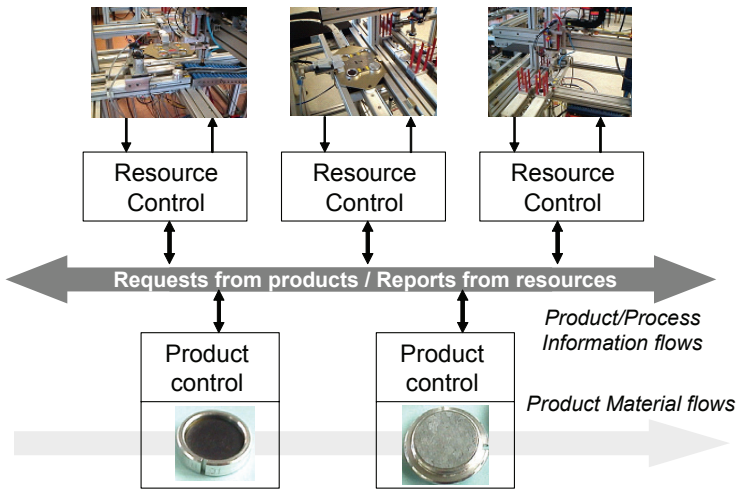

Fig. 3. Product-driven control architecture

This cooperation consists in the exchange of requests of operations (noted RQ) emitted by product controllers to resource controllers, and reports of operations (noted RP) emitted by resource controllers to product controllers.

The definition of these controllers are founded, on the one hand, on the modelling of the manufacturing system capabilities which describe the system topology and the manufacturing operations performed by each resource, and, on the other hand, on the modelling of product requirements in terms of the operations it has to undergo. Such controllers can be automatically and formally written by the use of the product-driven control synthesis, as proposed by Pétin et al. (2007). This synthesis is out of the scope of this paper which focuses on the implementation aspects of the product-driven control.

\section{TWO IMPLEMENTATION TECHNOLOGIES}

Many technologies can be tried to implement the concept of product-driven control. Amongst them, this part aims at comparing RFID tags and Wireless Sensor Networks nodes possibilities, as given by vendors in technical descriptions.

\subsection{RFID tags}

RFID corresponds to an automatic identification technology which relies on the remote reading and writing of information on electronic tags (also called RFID tags or transponders) (Finkenzeller 2003). RFID tags are at least composed of a chip and an antenna. In general, the chip contains a processor, a memory and a radio transmitter (Fig. 4).

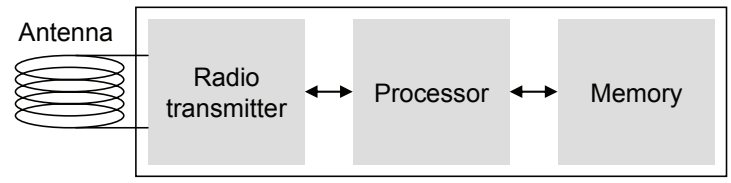

Fig. 4. Overview of an RFID tag structure

Some cheaper tags, which are the most used, are said "passive" because they have no internal power supply, do not contain an integrated circuit. They can be used for discrete identification. Many applications in product tracking, inventory systems and libraries can be found (see for example http://www.rfidjournal.com).

\subsection{WSN motes}

Emerging infotronics technology, as advances in microelectronics and wireless communications, have recently enabled the design of very tiny sensors. Such autonomous sensors nodes embed power supply, sensing, data processing, and wireless communication components (Akyildiz et al. 2002) and are used to build Wireless Sensor Networks (WSN). They are commonly called 'motes' (Fig. 5). With their capacities, motes can sense their physical environment, receive messages via the wireless network, and even react by making a decision or sending messages.

\begin{tabular}{|c|c|c|}
\hline $\begin{array}{c}\text { Communication } \\
\text { unit } \\
\text { (wireless network } \\
\text { protocols) }\end{array}$ & $\begin{array}{l}\text { Processing unit } \\
\text { \& memory } \\
\text { (OS \& algorithm) }\end{array}$ & $\begin{array}{l}\text { Sensing unit } \\
\text { (filtering and signal } \\
\text { adapting) }\end{array}$ \\
\hline$\uparrow$ & $\uparrow$ & $\uparrow$ \\
\hline \multicolumn{3}{|c|}{ (power management) } \\
\hline
\end{tabular}

Fig. 5. Functionnal view of mote components

WSN can be found into numerous military, environmental, human centric, robotics or logistics applications (Arampatzis et al. 2005).

\subsection{Implementation of product intelligence with tags or motes}

Both technologies present interesting capacities which could enable a more or less direct implementation of the concept of product-driven control into a physical product.

With the help of the literature and the description given by vendors about RFID (Finkenzeller 2003) and WSN (Akyildiz et al. 2002) technologies, Table 1 summarizes the abilities presented in technical descriptions of passive RFID tags, active RFID tags, and WSN motes to implement the various aspects of the product technical intelligence defined in (McFarlane et al. 2003) and presented in section 2. A passive RFID tag seems to be able to implement Level 1 product intelligence, while an active RFID tag containing a processor or a WSN mote seems to be able to implement Level 2 product intelligence.

Implementing product-driven control implies that, between products and resources, communications can effectively occur at each time. While the RFID technology needs a direct communication between tags and antennas (in this case, communications are limited by the existing infrastructure), ad-hoc organisation of WSN motes can be used to propagate messages. Such an ad-hoc organisation seems to be more flexible (as architecture, one bridge can be enough). For these reasons, WSN motes have been chosen in this study to experiment the implementation of product-driven control on a particular case study. 
Table 1. Comparison between RFID tags and WSN motes possibilities

\begin{tabular}{|c|c|c|c|c|}
\hline \multicolumn{2}{|r|}{ Aspects of technical intelligence } & Passive RFID tag & Active RFID tags & Mote \\
\hline 1 & Possess a unique identity & Yes & Yes & Yes \\
\hline 2 & $\begin{array}{l}\text { Be capable of communicating } \\
\text { effectively with its environment }\end{array}$ & $\begin{array}{l}\text { Yes, data can be requested by an } \\
\text { RFID reader }\end{array}$ & $\begin{array}{l}\text { Yes, data can be requested by an } \\
\text { RFID reader }\end{array}$ & $\begin{array}{l}\text { Yes, data can be send via UDP } \\
\text { protocol }\end{array}$ \\
\hline 3 & $\begin{array}{l}\text { Be able to retain or store data about } \\
\text { itself }\end{array}$ & Yes, contains a memory & Yes, contains a memory & Yes, contains a memory \\
\hline 4 & $\begin{array}{l}\text { Deploy a language to display its } \\
\text { features, production requirements, } \\
\text { etc. }\end{array}$ & $\begin{array}{c}\text { No, the memory only contains data, } \\
\text { not information }\end{array}$ & $\begin{array}{l}\text { Yes, the processor can interpret } \\
\text { memory data into product } \\
\text { information }\end{array}$ & $\begin{array}{l}\text { Yes, the processor can interpret } \\
\text { memory data into product } \\
\text { information }\end{array}$ \\
\hline 5 & $\begin{array}{l}\text { Be capable of participating in or } \\
\text { making decisions relevant to its } \\
\text { destiny }\end{array}$ & Not able to make decision & $\begin{array}{l}\text { Yes, able to make a decision using } \\
\text { an embedded algorithm }\end{array}$ & $\begin{array}{l}\text { Yes, able to make a decision using } \\
\text { an embedded algorithm }\end{array}$ \\
\hline
\end{tabular}

\section{CASE STUDY}

The implementation of the concept of product-driven control is tested with WSN motes in this paper on a scenario using the Flexible Assembly Cell case study of the AIP-Primeca Lorraine (http://www.aip-primeca.net).

\subsection{Presentation of the AIPL Case Study}

The cell involves six workstations which are interconnected by a conveyor: one station for pallet loading, four similar assembly stations, and one station for pallet unloading (Fig. 6). Six different product families can be assembled (Fig. 7). Each workstation is able to perform from 1 to 4 assembly operations and involves a vacuum generator and three air cylinders to handle parts and products.

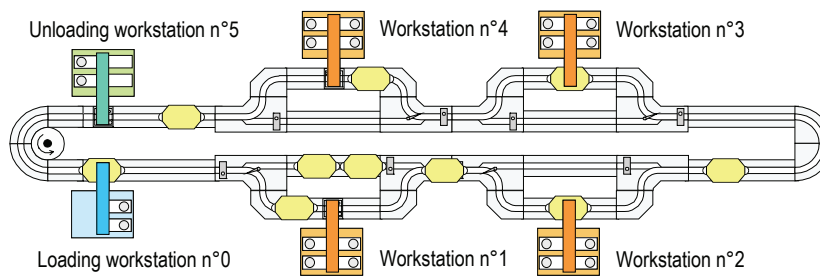

Fig. 6. AIPL Flexible Assembly Cell
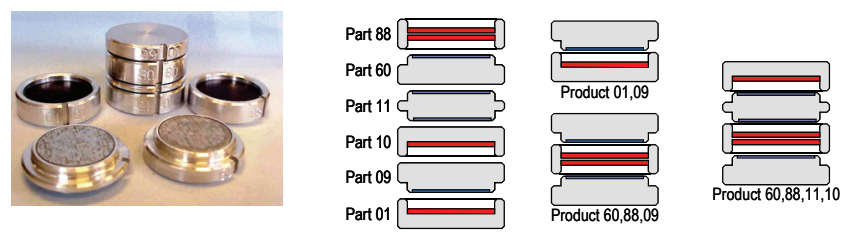

Fig. 7 AIPL Product types

Each pallet is equipped with a P-Particle C WSN mote (http://particle.teco.edu/) which implements the control part ('intelligent part') of products. A restriction is made so that each product will only go on one pallet during its assembly. Workstations are equipped with a Programmable Logic Controller (PLC), which implement resource controllers. The communication between product motes and resource controllers is ensured by an XBridge $($ ) which forwards UDP packets (used for the motes to communicate) from the WSN to the Industrial Ethernet and vice versa (Fig. 8).

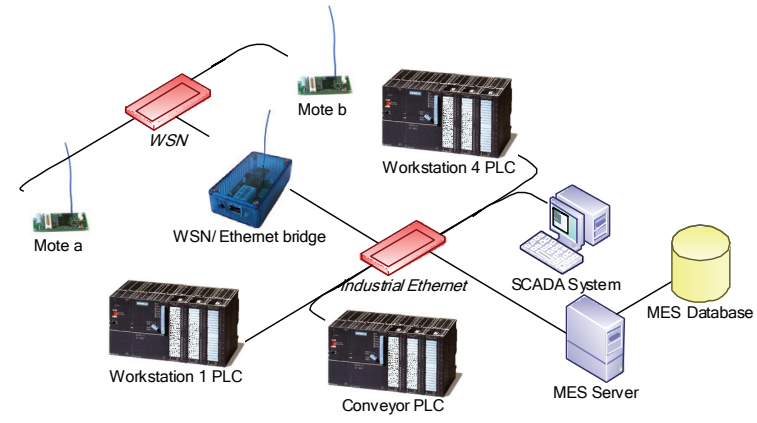

Fig. 8. Principle of the platform technical architecture

As seen in Fig. 9, this platform, currently under specification and development, plans product controllers to exchange Requests (RQ) and Reports (RP) with their environment.

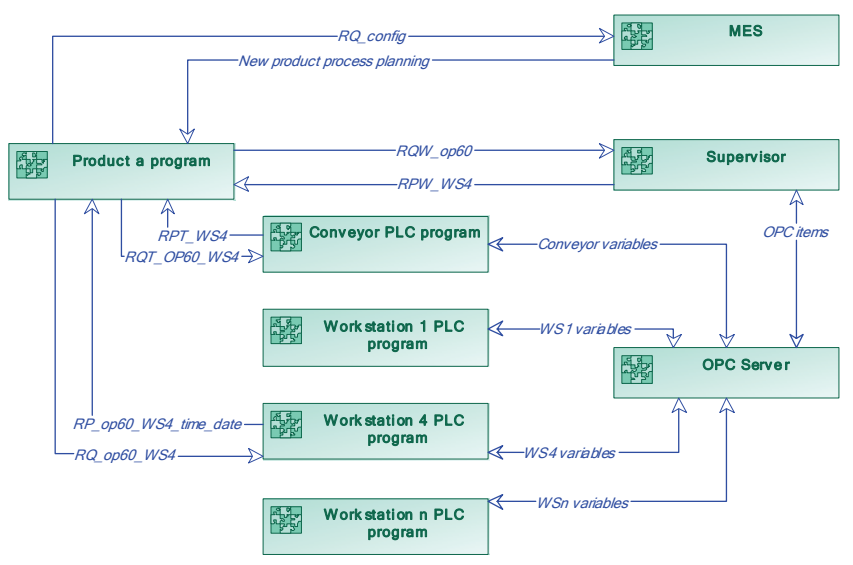

Fig. 9. Principle of the platform applicative architecture

To validate the implementation of level 1 and 2 of product intelligence, this paper focuses mainly on the product behaviour and communication. As the intelligent part of the product is implemented into motes, Teco Particle Analyser software is used to configure motes and to analyse their communications with external applications.

Motes are used to implement product intelligence only during the manufacturing. Once the product is manufactured, the corresponding mote memory is unloaded in order to store traceability information into the MES. The mote is then reconfigured in order to be used with a new product (Fig. 10). 


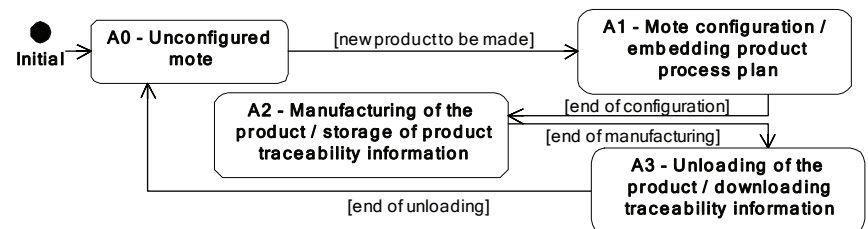

Fig. 10. Activity diagram showing mote and product stages during manufacturing

\subsection{Implementing level 1 product intelligence}

According to the definition given by Wong et al. (2002), level 1 intelligence refers to the ability of a product to cover points 1 to 3 of the definition: a unique identifier, ability to communicate and to store data about the itself.

In order to test this level of product intelligence, the configuration activity (A1 - Mote configuration / embedding product process planning) presented in Fig. 10 is considered. During this activity, detailed in Fig. 11, a mote which is not configured with a product ID and process plan emits periodically a request of configuration $(\mathrm{NCF})$. Once the manufacturing of a new product is planned by the supervisor or the MES, the mote is reconfigurated (a new ID and a new process plan). In order to acknowledge receipt of the configuration, the product mote sends an 'ELO' message, with the received configuration.

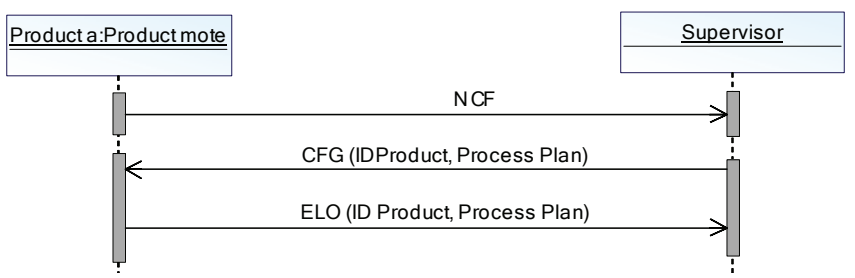

Fig. 11. Configuration sequence diagram

This scenario has been implemented on Particle $\subset$ motes (Fig. 12). The analysis shows that the product emits a 'NCF' message, containing the mote ID (2.232.0.0.0.77.220.181) corresponding to point 1 of (Wong et al. 2002). It receives the configuration (sequence 14 ' $\mathrm{CFG}$ ' with parameters ID of the product class, Class Number, Process Plan, ...\}), stores it and is able to communicate it (points $2 \& 3$ ) by broadcasting an 'ELO' message containing its ID (100 123) and its type (97).

\begin{tabular}{|c|c|c|c|c|c|c|c|}
\hline Sender ID & S.. & T... & Type & Data & Time & Date & Location \\
\hline $2 \cdot 232 \cdot 0 \cdot 0 \cdot 0 \cdot 77.220 .18$ & 1 & 91 & NCF & & $15: 21: 23$ & $20 / 09 / 2007$ & $\overline{114.111 .1}$ \\
\hline 2.232 .000 .0 .77 .220 .181 & 2 & 91 & NCF & & $15: 21: 32$ & $20 / 09 / 2007$ & 114.111 .1 \\
\hline 2.232 .0 .0 .0 .77 .220 .181 & 3 & 91 & NCF & & $15: 21: 41$ & $20 / 09 / 2007$ & 114.111 .1 \\
\hline 1.1 .1 .1 .193 .50 .39 .79 & 14 & 8 & CFG & & $15: 21: 41$ & $20 / 09 / 2007$ & 114.111 .1 \\
\hline 1.1.1.1.193.50.39.79 & 14 & $2 \ldots$ & IDP & 97 & $15: 21: 41$ & $20 / 09 / 2007$ & 114.111 .1 \\
\hline 1.1 .1 .1 .193 .50 .39 .79 & 14 & $1 \ldots$ & NUP & 100123 & $15: 21: 41$ & $20 / 09 / 2007$ & 114.111 .1 \\
\hline 1.1.1.1.193.50.39.79 & 14 & $1 \ldots$ & GAM & 60889000 & $15: 21: 41$ & $20 / 09 / 2007$ & 114.111.1 \\
\hline 1.1 .1 .1 .193 .50 .39 .79 & 14 & $1 \ldots$ & NAP & 1 & $15: 21: 41$ & $20 / 09 / 2007$ & 114.111 .1 \\
\hline 1.1 .11 .193 .50 .39 .79 & 14 & $1 \ldots$ & CAD & 223200077220181 & $15: 21: 41$ & $20 / 09 / 2007$ & 114.111 .1 \\
\hline $2.232 \cdot 0.0 .0 .77 .220 .181$ & 4 & 2. & ELO & 97100123 & $15: 21: 45$ & 20/09/2007 & 114.111 .1 \\
\hline
\end{tabular}

Fig. 12. Screenshot showing product and supervisor exchanges for the first experiment

This first experiment shows that WSN motes can implement at least level 1 product intelligence. A second scenario is needed to experiment if WSN motes are able to implement some more aspects of product intelligence.

\subsection{Implementing level 2 product intelligence}

As presented above, the level 2 of product intelligence defined in (Wong et al. 2002) corresponds, in addition to level 1 intelligence, to the ability of a product to deploy a language to communicate and to participate in decisions relevant to its destiny. The second experiment considers the activity A2 of Fig. 10, in which the manufacturing is driven by the product itself. The control is then based on the exchange, between the product and its environment, of Requests (RQ) and Reports (RP). A language is then defined as follows:

- RQW_op $:$ : request from the product: "which resource is able to perform operation i to me?"

- RPW_WS $\mathrm{j}_{\mathrm{O}_{0}} \mathrm{p}_{\mathrm{i}}$ : report from the supervisor: "the workstation $j$ is able to perform operation i" (the workstation is chosen by the supervisor in function of an optimization criteria, for example the waiting time)

- RQT_WS $\mathrm{j}_{-} \mathrm{op}_{\mathrm{i}}$ : request from the product to the conveyor: "bring me to workstation $\mathrm{j}$ for operation $\mathrm{i}$ "

- RPT_WS - $_{\mathrm{C}_{1}} \mathrm{op}_{\mathrm{i}}$ : report from the conveyor: "you are now at workstation $\mathrm{j}$ for operation i"

- $\quad R Q \_o p_{i} W_{j}$ : request from the product to workstation $\mathrm{j}$ : "perform me operation i"

- RP_op $\mathrm{p}_{\mathrm{i}} \mathrm{WS}_{\mathrm{j}}$ time date: workstation $\mathrm{j}$ reports to the product: "I performed you operation $i$ at time and date"

The 'intelligent part' of the product, is able to request operations and to receive reports of operations. The order in which the reports are emitted and the reports are waited is defined in the control part of product in function of the successive physical states of the product (Fig. 13) to ensure the correct execution of the process plan. A similar sequence is executed for each operation.

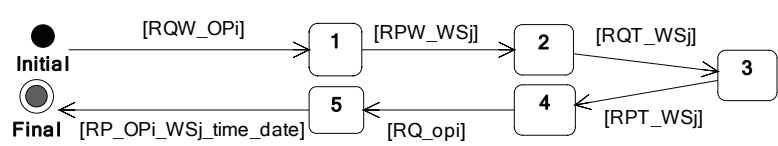

Fig. 13. Gerenic sequence of product internal behaviour

This internal behaviour can be formally synthesized as described in Pétin et al. (2007), but it is out of the scope of this paper. In addition, traceability information is stored in the product in function of manufacturing parameters which are given by resources.

An example of message exchange between product and external applications is shown in Fig. 14. The product requests resources to perform the operations scheduled in its process plan, in function of the reports it receives.

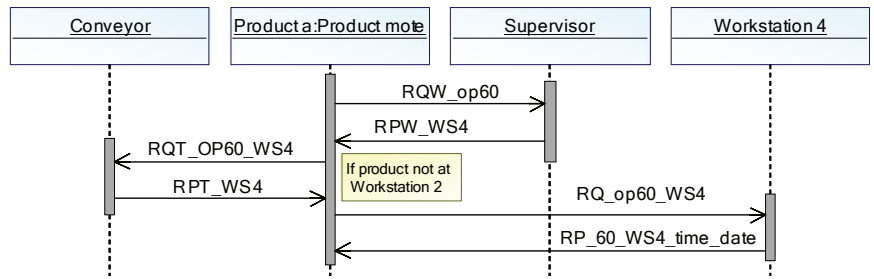

Fig. 14. Product and resource motes collaboration to perform operation 'op60' on workstation 4 
This example scenario has been successfully tested. Fig. 15 shows a screenshot with the exchange of product-driven control messages between a product, a resource and a supervisor. The product successively requests the operations which are relevant to its manufacturing (for example operations 60 and 88). Furthermore, traceability is ensured by the storage into the product of manufacturing conditions (e.g. operation 60 on workstation 4 , at $15: 35$ on September $20^{\text {th }}$ ).

\begin{tabular}{|c|c|c|c|c|c|c|c|}
\hline Sender ID & S.. & T... & Type & Data & Time & Date & Location \\
\hline $2 \cdot 232 \cdot 0 \cdot 0 \cdot 0.77 .220 .181$ & 22 & $2 \ldots$ & RQW & 60 & $15: 33: 31$ & $20 / 09 / 2007$ & 114.111 .1 \\
\hline 1.1 .1 .1 .192 .168 .8 .79 & 7 & $1 \ldots$ & RPW & 4 & 15:33:35 & $20 / 09 / 2007$ & 114.111.1 \\
\hline 1.1.1.1.192.168.8.79 & 7 & $1 \ldots$ & $C A D$ & 223200077220181 & $15: 33: 35$ & $20 / 09 / 2007$ & 114.111 .1 \\
\hline 2.232 .0 .0 .0 .77 .220 .181 & 23 & $2 \ldots$ & RQT & 604 & 15:33:38 & 20/09/2007 & 114.111 .1 \\
\hline 1.1.1.1.192.168.8.79 & 8 & $2 \ldots$ & RPT & 4 & $15: 33: 59$ & $20 / 09 / 2007$ & 114.111 .1 \\
\hline 1.1.1.1.192.168.8.79 & 8 & $1 \ldots$ & $C A D$ & 223200077220181 & $15: 33: 59$ & $20 / 09 / 2007$ & 114.111 .1 \\
\hline 2.232 .0 .0 .0 .77 .220 .181 & 24 & $2 \ldots$ & $\mathrm{RQ}$ & 604 & $15: 34: 07$ & $20 / 09 / 2007$ & 114.111 .1 \\
\hline 1.1.1.1.192.168.8.79 & 9 & $1 \ldots$ & $\mathrm{RP}$ & 60415352097 & $15: 35: 06$ & $20 / 09 / 2007$ & 114.111 .1 \\
\hline 1.1.1.1.192.168.8.79 & 9 & $1 \ldots$ & $C A D$ & 223200077220181 & $15: 35: 06$ & $20 / 09 / 2007$ & 114.111 .1 \\
\hline $2.232 .0 \cdot 0.0 .77 .220 .181$ & 25 & $2 \ldots$ & RQW & 88 & $15: 35: 11$ & $20 / 09 / 2007$ & 114.111 .1 \\
\hline
\end{tabular}

Fig. 15. Screenshot showing product message exchanges for the second experiment

\section{CONCLUSION AND OPEN ISSUES}

This paper focuses on the possibilities to implement the concept of product-driven control on a case study using motes of wireless sensor networks. WSN, compared with RFID, allow guaranteeing the continuity of information availability during the overall manufacturing process of products. The use of the Particle Analyser showed that it is possible with motes, on a simple example, to cover level 1 and 2 of product intelligence, as defined by Wong et al. (2007). Traceability is also ensured by storing manufacturing operation information directly into the product.

Issues are now open on the efficiency of the concept implementation by putting various product instances in a real manufacturing environment. This will underline communication and product conflict problems. The last ones may be solved by the development of a 'staff holon' as defined by Van Brussels et al. (1998). WSN sensing abilities (temperature, distances between motes, acceleration ...) will also be used to situate and to monitor products in their environment. Such data may be taken in account by products in their decision making to ensure quality and to optimize manufacturing flows.

\section{REFERENCES}

Akyildiz I.F., W. Su, Y. Sankarasubramaniam, E. Cayirci (2002). Wireless sensor networks: a survey. Computer networks, 38, pp. 393-422.

Arampatzis Th., J. Lygeros, S. Manesis (2005). A survey of applications of wireless sensors and wireless sensor networks, Proceedings of the $13^{\text {th }}$ Mediterranean Conference on Control and Automation, Limassol, Cyprus, June 27-29, pp. 719-724.

Babiceanu R. F., F. F. Chen (2006). Development and applications of holonic manufacturing systems: a survey, Journal of Intelligent Manufacturing, 17, pp. 111-131.

Chirn J.-L., D. McFarlane (2005). Evaluating holonic control systems: a case study. Proceedings of the $16^{\text {th }}$ IFAC world congress in Prague, Elsevier, ISBN 008045108X.
Da Silveira G., D. Borenstein, F.S. Fogliatto (2001). Mass customization: literature review and research directions. Int. Journal of Production Economics, 72, pp 1-13.

Deen, S.M. (Editor) (2003). Agent-based manufacturing Advances in the holonic approach, Springer, ISBN 3540-44069-0.

Finkenzeller K. (2003). RFID handbook: fundamentals and application in contactless smart cards and indentification, J. Wiley and Son, ISBN 0-470-84402-7.

International Organisation for Standardization (2003). ISO 62264: enterprise-control system integration.

Hollocks B.W., H.T. Goranson, D.N. Shorter, F.B. Vernadat (1997). Assessing enterprise integration for competitive advantage, ICEIMT'97, International Conference on Enterprise Modelling and Modelling Technology, Berlin.

Karkkainen M., J. Holmstrom, K. Framling, K. Artto (2003). Intelligent products - a step towards a more effective project delivery chain, Computers in Industry, 50, pp. 141-151.

Koestler A. (1967). The ghost in the machine, ISBN 0-14019162-5.

Leitão P., F. Restivo (2006). ADACOR: A Holonic architecture for agile and adaptive manufacturing control, Computers in Industry, 57, pp. 121-130.

Marik V., J. Lazansky (2006). Industrial application of agent technologies, Control Engineering Practice, doi:10.1016/j.conengprac.2006.10.001.

McFarlane D., S. Sarma, J.L. Chirn, C.Y. Wong, K. Ashton (2003). Auto id systems and intelligent manufacturing control, Engineering Application of Artificial Intelligence, 16 (4), pp. 365-376.

Morel G., H. Panetto, M. Zaremba, F. Mayer (2003). Manufacturing enterprise control and management system engineering: rationales and open issues. IFAC Annual Reviews in Control, 27 (2), pp. 199-209.

Morel G., P. Valckenaers, J.M. Faure, C. Pereira, C. Diedrich (2005). Survey paper on manufacturing plant control challenges and issues, Proceedings of the $16^{\text {th }}$ IFAC world congress in Prague, ISBN 008045108X.

Nof S. Y., G. Morel, L. Monostori, A. Molina, F. Filip (2006). From plant and logistics control to multienterprise collaboration, IFAC annual reviews in control, 30 (1), pp. 55-68.

Pétin J.-F., D. Gouyon, G. Morel (2007). Supervisory synthesis for product-driven automation and its application to a flexible assembly cell, Control Engineering Practice, 15, pp. 595-614.

Valckenaers P. (Editor) (2001). Special issue: Holonic Manufacturing Systems, Computers In Industry, 46 (3), pp. 233-331.

Van Brussel H., J. Wyns, P. valckenaers, L. Bongaerts, P. Peeters (1998). Reference architecture for holonic manufacturing systems: PROSA, Computers in Industry, 37 (3), pp. 255-274.

Wong C.Y., D. McFarlane, A. A. Ahmad Zaharudin, V. Agarwal (2002). The intelligent product-driven supply chain, IEEE International Conference on Systems, Man and Cybernetics. 